\title{
THE GOVERNANCE OF COVID-19 PANDEMIC HEALTH EMERGENCY IN ITALY: A CONSTITUTIONAL PERSPECTIVE
}

\begin{abstract}
The essay focuses on the measures that have been taken in Italy to limit the contagion with Coronavirus in the first phase of the health emergency in 2020. The Italian Government was the first to face the epidemiological crisis in a constitutional democracy. The lockdown was one of the most drastic in Europe. On the one hand, fundamental freedoms of individuals have been compressed; on the other, the objective of limiting the expansion of the contagion in the early stage of pandemic expansion has been achieved, probably saving all European countries from an ungovernable health crisis before a minimal preparation. Even some critical aspects in the decision making process could be highlighted from a constitutional law perspective, the Author believes that the temporary measures, although drastic, not exceeded the limits allowed by the Italian Constitution, nor they seriously affected the balance between the powers at least in the first/second phase.

The majority of Parliament approved ex post the law-decrees adopted by the Council of Ministers, demonstrating that it share the Government's political position. Furthermore, in a very short time, the Italian people, in their vast majority, spontaneously adapted to the imposed prohibitions, demonstrating a sense of responsibility and solidarity towards the most vulnerable categories with respect to the effects of the virus (elderly and sick people, for example).

The reasons of the economy, which would have required not to stop business activities, have been temporarily recessive with respect to the protection of the health of the community. This decision seems to find its ultimate foundation in the Article 2 of the Italian Constitution which requires everyone to respect the duty of social solidarity.
\end{abstract}

Keywords: pandemic, COVID-19, emergency, constitutional law, fundamental rights, emergency powers.

\section{ZARZĄDZANIE STANEM ZAGROŻENIA ZDROWIA W CZASIE PANDEMII COVID-19 WE WLOSZECH: PERSPEKTYWA KONSTYTUCYJNA}

Streszczenie. Tekst koncentruje się na środkach, jakie zostały podjęte we Włoszech w celu ograniczenia zarażenia koronawirusem w pierwszej fazie zagrożenia zdrowia w 2020 r. Rząd włoski jako pierwszy zmierzył się z kryzysem epidemiologicznym w demokracji konstytucyjnej. Lockdown był jednym $\mathrm{z}$ najbardziej drastycznych $\mathrm{w}$ Europie. $\mathrm{Z}$ jednej strony ograniczono podstawowe wolności jednostki; z drugiej - udało się ograniczyć rozprzestrzenianie wirusa we wczesnej fazie ekspansji pandemicznej, prawdopodobnie ratując wszystkie kraje europejskie przed niemożliwym do opanowania kryzysem zdrowotnym, przy minimalnym przygotowaniu. Nawet jeśli niektóre aspekty procesu decyzyjnego można by podkreślić w perspektywie prawa konstytucyjnego, to

\footnotetext{
*University of Macerata, Department of Law, angela.cossiri@unimc.it
} 
zdaniem Autorki środki tymczasowe, choć drastyczne, nie przekroczyły granic dozwolonych przez włoską konstytucję, ani nie wpłynęły poważnie na równowagę między władzami przynajmniej w pierwszej/drugiej fazie.

Większość parlamentarna zatwierdziła ex post dekrety uchwalone przez Radę Ministrów wykazując, że podziela stanowisko polityczne rządu. Ponadto w bardzo krótkim czasie naród włoski w zdecydowanej większości spontanicznie dostosował się do nałożonych zakazów, wykazując poczucie odpowiedzialności i solidarności wobec najbardziej narażonych na skutki wirusa grup (na przykład osoby starsze i chore). Względy ekonomiczne, przemawiające za niewstrzymywaniem działalności gospodarczej, były czasowo recesyjne wobec ochrony zdrowia społecznego. Wydaje się, że decyzja ta znajduje ostateczną podstawę w art. 2 włoskiej konstytucji, który zobowiązuje wszystkich do poszanowania obowiązku solidarności społecznej.

Słowa kluczowe: pandemia, COVID-19, stan nadzwyczajny, prawo konstytucyjne, prawa podstawowe, uprawnienia nadzwyczajne.

\section{WHAT HAPPENED IN ITALY}

The measures to combat the contagion of the COVID-19 virus adopted in Italy, as well as in other European countries, are a set of detailed and temporary rules impactful on individual and collective life. In order to manage and contain the health emergency, the normality of individual life and productive activities has been temporarily suspended. Some fundamental freedoms have also been limited. The "crisis protocol" culminated in the ban on leaving homes for the majority of the population, which lasted for several weeks. For this institute was globally used the Anglo-Saxon term "lockdown."

In Italy, the first lockdown began on 24 February 2020, covering some municipalities of Lombardy and Veneto Regions. The quarantined "red zone" affected in these first days around 50,000 people. The lockdown was initially meant to last until 6 March. As the Coronavirus contagion continued to increase, on Sunday 8 March, Italian Prime Minister Conte announced the expansion of the red zone in northern Italy, affecting over sixteen million people, covering entirety of the region of Lombardy and fourteen provinces in Piedmont, Veneto, EmiliaRomagna, and Marche Regions.

On the evening of 9 March, was announced that the quarantine measures were expanded to the entire country. Therefore Italy was the first democratic country to implement a national quarantine as a result of the 2020 coronavirus emergency. The lockdown in this case was meant to last until 3 April. On 21 March, Conte announced a further enlargement of the lockdown, by shutting down all nonnecessary industries. Thus the Italian production system was extremely slowed down. Businesses and Public administrations were invited to implement "smart working processes" to permit employees to work from home. The lockdown was repeatedly extended until 3 May. 
In this phase, called "phase 1", the ban on leaving home was never an "absolute ban": people would still be able to move nearby for necessity (i.e. to buy food and drugs), for work needs and for health reasons.

The lockdown measures implemented by Italian Government were considered the most radical actions implemented against the outbreak outside of the lockdown measures implemented in China. Only workers in essential economic sectors (such as healthcare and food production chain) were allowed to continue their jobs.

So drastic measures were criticized by political oppositions and by some President of Regions; ${ }^{1}$ but they achieved the objective pursued: also in the most affected zones, in the northern Italy, the epidemic was contained; the contagion curve felled and it was possible to support with adequate care in the hospitals all the most serious patients, through the public health system. The greatest risk was thus averted: the danger of not being able to ensure access to intensive care units and respirators for everyone who need them. In fact, intensive care units in Italy had a limited number of places (just over 5,000), which was insufficient for exceptional needs. As highlighted on 7 July 2020 in a public meeting by former President of the European Commission Romano Prodi, Italian political decisions in the first phase have also avoided spreading the epidemic out of control in Europe, basically saving the other countries from a situation that could no longer be governed.

On 26 April, the Prime Minister announced the so-called "phase 2", that would start from 4 May. Gradually movements in the country were allowed (before between municipality and then across Regions) and the re-opening of closed economic activity was permitted, even schools rested closed. In phase 2, the protection from Coronavirus is entrusted to the obligation of social distancing: it is forbidden in all the activities to decrease the distances between people below a measure considered safe according to the context. In the most of cases personal protective equipment, such as face masks, were mandatory.

\section{ANTI-CONTAGION RULES FROM THE PERSPECTIVE OF CONSTITUTIONAL LAW}

The "totalitarian" system of emergency discipline, which pervades the details of daily life and human actions, is not new in the history of law; on the contrary, it is typical of the government of epidemics, of which the plague is the best known paradigm.

This discipline is particularly interesting for contemporary constitutionalism, because it represents the first and most significant limitation of fundamental

\footnotetext{
${ }^{1}$ On this issue, see Di Cosimo, Menegus (2020).
} 
freedoms ever experienced in the history of modern democracies. In Italy, this was the heaviest restriction of freedom experimented in Republican historical phase.

Fundamental rights, such as freedom of movement, assembly, worship, economic action, freedom of self-determination in healthcare are concerned; but also social rights, such as work, school, health and access to justice, have undergone compressions and modulations not imaginable before the pandemic.

A significant impact is also on the principle of non-discrimination. The European Agency for the Protection of Human Rights published three Reports of analysis on the impact of the COVID-19 emergency in the EU (European Agency for Human Rights 2020): the limitations of the fundamental rights adopted by the governments of the Member States to protect health had important asymmetric effects on human rights for some vulnerable categories of individuals. Inter alia, older people, children and women suffered more the damage; but also sick and disabled people, homeless, prisoners, political refugees, minorities target for racist episodes were particularly affected (for example, in the first moment, the Chinese community permanently residing in Italy). We cannot forget the difference in the impact of the measures - but also of their medium and long-term economic consequences - on the economically disadvantaged social classes, or on vulnerable categories of workers, such as "precarious" ones, not sufficiently guaranteed in the rights and sometimes also in health safety.

Finally, it is necessary to consider consider how much the so called "digital divide" can weigh, distinguishing between those who have effective and adequate access to information technologies - in particular, through the personal availability of electronic tools and an efficient internet access - and those who are totally or partially excluded from them, for economic reasons or skill deficit.

Anyway, it does not appear that the governance of the pandemic has overturned the fundamental connotations of the Italian constitutional system, nor that it has produced in the general case, even embryonically and temporarily, a "State of exception." On the contrary, the exercise of public power, justified by the seriousness of the situation, seems to have remained within the boundary allowed by the constitutional design at least in the first phase and in the mid-term.

\section{THE CONSTITUTIONAL FRAMEWORK IN ITALY}

The Italian Constitution, unlike other Constitutions, does not contain a specific discipline for the emergency. It, however, establishes a type of subconstitutional source of law - so called law-decree - which can be adopted by Government "in extraordinary cases of necessity and urgency" (Article 77). This type of act should be used precisely to face unexpected serious situations. The lawdecree, once approved by the Council of Ministers and published in the Official Journal, comes into force immediately. It lasts only 60 days. Within this time, 
Parliament can convert it into a law. Otherwise, the law-decree decays and loses effectiveness with retroactive effects.

The Italian Constitution also expressly accepts certain restrictions on freedoms. For example, Article 16 guarantees freedom of movement "unless the law imposes limits for health or safety reasons." Article 17 establishes that a meeting in a public place may be prohibited by Public Authorities for "proven reasons of public safety." In some cases, the Constitution expressly requires that certain restrictions have to be established through primary sources, i.e. from a hierarchical level immediately below the Constitution. In fact, only primary sources are adopted through a procedure, which guarantees voice to oppositions and public transparency

Finally, it has to be considered that in the pandemic the limitations of fundamental freedoms are justified by the need to protect another fundamental right of individuals, guaranteed by Article 32: the right to health protection. The problem is therefore framed in the balance among competing fundamental rights and constitutional interests.

\section{THE GOVERNANCE IN THE EARLY STAGES OF HEALTH EMERGENCY IN ITALY}

In this framework, with the aim of containing contagion, in the early stages of the epidemical expansion the restrictions of freedoms have been introduced through some law-decrees, adopted by the Italian Government. ${ }^{2}$ These are the law-decrees No. 6, 19 and 33 of 2020, the first two already converted into law by Italian Parliament This means that the Government has received the political support of the parliamentary majority on its political action (Di Cosimo 2020). The use of a primary source, such as the law-decree, guarantees compliance with the constitutional rules.

The government, through the first law-decree (23 February 2020), declared the state of emergency for six months, until the $31^{\text {th }}$ of July 2020; the second law-decree established that rights and freedom restrictions can be taken only for temporary periods, each lasting no more than thirty days, according to the need of the moment.

For this reasons, the government have not altered the balance between the powers of the State; the Parliament has not suffered a reduction of its role, nor the other constitutional bodies, which continued to work on a regular basis, albeit through remote technological system and slow-motion rhythm.

${ }^{2}$ All the measures adopted by the Italian Government relative to the COVID-19 emergency are available on this webpage: http://www.protezionecivile.gov.it/en/risk-activities/health-risk/ emergencies/coronavirus/legal-misure-emergency-coronavirus 


\section{SOME CRITICAL ASPECTS}

The first decree broadly sets out measures to contain the epidemic, but also refers to another regulatory instrument, adopted directly by the President of the Council (Decree of the President of the Council of Ministers, so called, in Italian language acronym, "DPCM"). Through this tool, repeatedly used, more punctual and concrete restrictions have been introduced, directly limiting fundamental rights. However, the legal basis (the law-decree) does not adequately circumscribe and delimit the ambit of the "DPCM." This therefore raises doubts about compliance with the Constitutional framework, especially because the decree of the President of the Council is an act that does not involve Parliament, unlike the law-decree.

Also thanks to this instrument, in this phase the President of the Council assumed a media pre-eminence in the emergency governance, with respect both to the other members of the Government and to the Parliament. In particular, the two Chambers were involved in the decision making process and could express their voice for the first time only on the $5^{\text {th }}$ of March, when the first law-decree was discussed to be converted into law.

During the parliamentary discussion on the second law-decree, an amendment was introduced, allowing the so called "parliamentarization" of the decision making process of the "DPCM." The amendment provided the prior illustration of the contents of "DPCM" to consider the opinion of the Chambers, unless reason of urgency. This exception is a weak point of the reform, because the Government itself decides whether or not there are such reasons. The reform also reduces Parliament's role and Chambers seem to have a role of Government consultant.

With the second law-decree, the problem that emerged in the earlier stage was in some way overcome: a more precise indication of the measures to contain the epidemic were provided; so the President of the Council could only adopt his decree within a limited margins of autonomy.

\section{THE CONDITIONS FOR LIMITING RIGHTS AND FREEDOMS IN A CONSTITUTIONAL DEMOCRACY}

Apart from the specific problem of the type of source of law used, the question is whether it is legal to limit fundamental freedoms in a constitutional democracy. If it is, we need to understand to what extent and how it can be restricted.

In order to answer to the first questions, it is necessary to refer to the first postulate of the general theory of fundamental rights: no right is absolute and all fundamental rights and freedoms can be limited, according to the technique of balancing, when this is required by the protection of other competing fundamental freedoms. 
The limitation of rights is immediate and direct connected to the fact that they insist "on the same space", which is a "zero-sum" space; rights and freedoms are brought to conflict with each other by the complex dynamics of human life. The ultimate constitutional root of this postulate seems to be, in the Italian constitutional framework, in Article 2: it states that "The Republic recognizes and guarantees the inviolable human rights [...], and requires the fulfillment of the mandatory duties of political, economic and social solidarity." The duty of solidarity can easily be forgotten, because - tax obligation aside - it is a legal positions which very rarely come into action. Anyway it is the other side of fundamental rights and freedoms, representing their economic and noneconomic costs (Holmes, Sunstein 2013). I highlight the duties of solidarity, because the containment legislation represents first and foremost a protection of most vulnerable minorities to contagion put in place by the whole of the social community: we refer to categories such as elderly and immune-depressed people, individuals with different clinical pathologies, etc., particularly exposed to the risk of the COVID-19 infection more serious consequences.

The second question is: to what extent can fundamental freedoms be restricted? In order to answer, it is necessary to consider the scheme of balancing judgment, used by Constitutional Court to verify the correctness of the measures prepared by the legislators; particularly the last step of this scheme could be focused.

To limit fundamental rights, the legislator must respect specific conditions imposed by the constitutional design. First of all, the compression of fundamental position(s) must be necessary for the protection of other fundamental position(s); therefore, the restriction of fundamental freedoms must respect the criterion of proportionality: the compression is allowed within the minimum measure required to protect the competing fundamental position and not beyond, without exceeding what is strictly necessary. From this point of view, the restrictive measures must be temporary and the term must be reasonable. This criterion could be scrutinized by Constitutional Court, for example if there will be judicial appeal against applied penalties.

\section{CONCLUDING REMARKS: \\ A "PEDAGOGICAL" ROLE FOR ANTI-CONTAGION RULES?}

An emerging and unprecedented situation such as the one addressed in 2020 in many democratic countries seems to have placed in the foreground a "primitive" and anthropological function of the law, usually out of the horizon of the modern positive jurist. Law is useful for instilling individual and collective behaviors, a group practice. Italians very quickly had to move from the denialism (or minimization) of the phenomenon, to which economic reasons 
and public stances of some scientists have contributed, to the collective sharing of a responsibility. Rather than nominating behavior as legal or illegal, the law was functional in the early stage of the health emergency to guide the action of a community, the first which passed through the experience of the pandemic in a democratic State.

It was essential, that the public authorities - called to govern the situation - ensured, together with health protection of collectivity, social cohesion and ensured consensus, even in a context, rich in differences. In this framework, the effectiveness of the law, or its capacity to impose a practice through a coercible penalty, appears to be totally secondary. The success of the rules could only be put back to the control of the same citizenship, overshadowing the formal control, which certainly maintained only a residual preventive function. The relationship between rules and regularity reveals an additional element of complexity, proposing the ancient question of a polysemantic "nomos."

From this point of view, some elements are interesting: if the were read in a strictly positive perspective - as generally - they represent defects and criticality, while - if they were included in the proposed perspective express a coherent logos: first of all, the gradualism in the introduction of prohibitions - which is certainly also the result of understandable uncertainties of public decision-makers in facing an unprecedented challenge - may have been useful in the progressive maturation of collective awareness. Secondly, the weakness of the prescriptive perspective is demonstrated by the progressive reduction in the penalty: the criminal penalty, introduced in the first place, for any violation has been replaced by administrative one; the administrative penalty was reduced, compared to what was originally planned, through an amendment approved during the conversion of the law-decree establishing the prohibition. If much has already been done by the legislator, even in constant of emergency, it can be assumed that the sanctioning system will be further weakened both in the administrative application of the rules and in the case-law. Finally, the technique that uses very general clauses to allow behaviors (such as "necessity" or, in the second phase, "visit kin") on the one hand has urged criticism because it is unclearness, able to compromise certainty and predictability of the law; but, on the other hand, it can be read as a choice (more or less aware) of the legislator, which puts the assessment of the concrete case back to the appreciation of the interpreter.

Modern law does not consist, in fact, only in acts of imperiousness, exercise of the legislative function, but also in interpretations, which do not ignore the particular situations in which they are located. Interpretation constitutes a process that, starting from the provision formulated by the legislature in general and abstract terms (the sign or signifier, using the language of semiotics), seeks and identifies the appropriate norm for the specific case, assigning a specific meaning to the linguistic statement: so "fact" and "right" turn out to be inseparable elements. This is especially true for abstract principles and non-circumstantial 
and highly generic clauses, which have necessarily be intended in the concrete meanings, appropriately contextualized.

The proposed thesis does not exempt the legislation from a criticism: in the whole of the discipline of combating contagion there is a fundamental mix-up between the legal dimension and the ethical one. This is unusual in a democratic State. This overlapping of levels can be hardly sustain outside an extraordinarily exceptional situation, in which there are no alternatives. One thing, in fact, is obedience, another responsibility; and the instruments to favor them are different: the first one is realized by the imposition of the state law; the second should not be promoted by the use of public force.

However, it is not possible to establish ex post, if merely "pedagogical" invitation - for example recommendations made by the public authorities, such as the suggestion to not leave their homes to the elderly people, contained in the second decree-law - would had the same impact on the general practice of the whole community. The unprecedented for constitutional democracy, the extraordinary exceptionality of the event, its continuous character seem to justify the line adopted by the legislator. At the same time, the rigidity of the ban may (and probably should) be corrected by appropriately contextualized interpretations and mitigated cum grain salis, where necessary, carefully reconstructing the regulatory rationes.

\section{BIBLIOGRAPHY}

Di Cosimo, Giovanni. 2020. "Tra decreti e decreti: l'importanza di usare lo strumento giusto." LaCostituzione, April 22, 2020. https://www.lacostituzione.info/index.php/2020/04/22/tradecreti-e-decreti-limportanza-di-usare-lo-strumento-giusto/

Di Cosimo, Giovanni. Giacomo Menegus. 2020. “L'emergenza Coronavirus tra Stato e Regioni: alla ricerca della leale collaborazione.” BioLaw Journal 2. http://rivista.biodiritto.org/ojs/index.ph p?journal $=$ biolaw \&page $=$ article \&op $=$ view\&path $\% 5 \mathrm{~B} \% 5 \mathrm{D}=576 \&$ path $\% 5 \mathrm{~B} \% 5 \mathrm{D}=467$

European Agency for Human Rights. 2020. Coronavirus Pandemic in the EU. Fundamental Rights Implications. Bulletin 1. Louxemburg: European Union Agency for Fundamental Rights. https://fra.europa.eu/en/publication/2020/covid19-rights-impact-april-1

Holmes, Stephen. Cass R. Sunstein. 2013. The Cost of Rights: Why Liberty Depends on Taxes. New York: W. W. Norton \& Company.

\section{Internet sources}

http://www.fra.europa.eu

http://www.lacostituzione.info

http://www.protezionecivile.gov.it/en/risk-activities/health-risk/emergencies/coronavirus/legalmisure-emergency-coronavirus

http://www.rivista.biodiritto.org

(C) by the author, licensee Łódź University - Łódź University Press, Łódź, Poland. This article is an open access article distributed under the terms and conditions of the Creative Commons Attribution License CC BY-NC-ND 4.0 (https://creativecommons.org/licenses/by-nc-nd/4.0/) 